IC Vol. $5 N^{\circ}$ 2: pp. 313-319, 2014

\title{
NAVEGANTE DE ESTOS \\ Y OTROS OCÉANOS
}

\author{
Danilo Sánchez Lihón ${ }^{I}$
}

\section{El hombre total $y$ fatal}

En el libro Arte de navegar el poeta Juan Ojeda indaga por una verdad dentro de lo oscuro, hosco y tenebroso, válida para el Hombre como conjunto. Hay allí un primer acto de valor: el identificarse, comprometerse y responsabilizarse por lo que es comprender una realidad trascendente para construir una humanidad verdadera, fundada en el abrazo y la solidaridad.

Ante las preguntas esenciales sus respuestas son tan demoledoras y funestas que le hicieron perder toda esperanza: ¿Hacia dónde vamos? ¿Cuál es el destino final del Hombre? ¿Cuáles los signos ocultos de la condición humana? ¿Cuál el designio de Dios? ¿Hay Dios?

Fue osado, directo y sin ambages, no tanto en plantearse tales cuestiones que son más bien las que todos nos hacemos, sino en lo implacable de las respuestas.

Lo peculiar fue primero ser riguroso y acendrado en los métodos y exhaustivo al recurrir a diversos saberes, ciencias y artes consumadas, religiones y arduas filosofías para obtener respuestas a tales indagaciones. Pero era conmovedor ver en su elección que el pábulo a tales preguntas él al final esperaba que las dé la candorosa poesía que él la asume por completo.

Macizas y agobiantes fueron las respuestas -por lo infelices y calamitosas-, lo que constituyó parte fundamental en el motivo de su inmolación. Pre-

* Recibido: 19 agosto 2014; aprobado: 21 noviembre 2014.

1 Escritor. Profesor en la Universidad Nacional Mayor de San Marcos. Director del Proyecto "Capulí, Vallejo y su tierra”. Email: dsanchezlihon@aol.com, danilosanchezlihon@gmail.com. 
guntas que todos escondemos por comodidad, miedo o impotencia, por cuyas respuestas Juan indagó acuciosamente. Cuando caminábamos juntos siempre recaía en que la verdadera y sincera indagación filosófica y metafísica era morir porque allí recién sabríamos la verdad total. Y su suicidio fue parte de ese acto de coraje. Y me pregunto: ¿qué es lo que ahora él sabrá?

\section{Dolor vertical}

Aquí las respuestas le fueron adversas, negativas y horrendas.

¿Ocultarlas a sí mismo? ¿Esconderse de ellas? ¿Manipularlas? ¿Buscar refugio en algún empleo, bien o mal remunerado? Esta fue una de sus conclusiones:

Todo es pánico, inmóvil duración.

Su proeza es trascendente porque él asume el destino del Hombre, pues hacía tiempo que dejó de hablar como individuo para hablar como especie representando al género humano que sobrelleva un destino y determinadas condiciones que lo enajenan.

A través de Juan habla la historia y su verbo tiene la densidad de siglos y milenios vividos.

Combado de soledad y neutro polvo hurga sus ojos.

Él es la esencia del estupor de la raza humana. No del dolor vertical, explicable desde las circunstancias se la vida sino del horror horizontal, permanente y no enmendable.

Horror ante un proyecto humano y cósmico que él intuye o conoce deforme y pavoroso, cual es el rodar del mundo hacia el vacío.

Es la visión terrorífica y espantosa que también diera en parte el evangelista del Apocalipsis, solo que en el caso de este último amparado y pretejido en una creencia, una fe y ante el descalabro una última esperanza.

\section{Nada hay}

Horror de una catástrofe que se remonta al origen de la creación, como un aborto divino interminable:

donde Nacimiento y Muerte, Putrefacción y Crecimiento, son columnas quebradas

que un ojo perverso contempla torpemente".

"Tal vez somos un don abolido por el nacimiento. 
Las respuestas a sus indagaciones son estremecedoras. Hay un resultado de espanto, consecuencia del examen que arroja en sus proyecciones la ciencia; conclusión y síntesis de su sabiduría del mundo que derivan en ser abrumadoras y lacerantes y ante lo cual ¡qué olvidado, distraído y banal se siente al Hombre frente a ese sino fatal que lo marca desde antes de nacer! ¿Qué indefensas y vulnerables resultan ser sus condiciones!

Trance de filosofía, poesía, ciencia, religión y moral, donde lo superfluo no ingresa y todo lo esencial se hace trizas. Donde sólo la sombra de nuestro destino permanece, que las almas en breve rumor de culpa y añoranza logran esconder en el pavoroso escenario donde todas las imágenes son abominables.

Y los significados ignominiosos, dichos en idiomas soterrados, con voces veladas, en instantes que fueron, pero ya dejaron de ser, supremos.

Nuestro indagar ha concluido

Y ésta es la sabiduría: nada hay

Que explorar fuera de la fábula...

\section{El descenso y caída}

¿De dónde deriva la noción, y hasta el sentimiento de tragedia, en Juan Ojeda?

De la convicción de que estuvimos hechos para ser dioses y hemos rodado a una condición banal y efímera.

De que hemos sido expulsados del paraíso y después hemos ido perdiendo día a día inocencia y sabiduría.

Hasta caer despojados de todas las virtudes, en el pozo ciego y perverso de la futilidad y, consecuentemente, en la condena al infierno.

Tierra de los dioses que el hombre habita,

y bajo el murmullo del tiempo una muerte segura.

En la proyección del tiempo pasado, presente y futuro, Ojeda encuentra una línea de descenso, caducidad e ignominia.

He allí la clave de su desencanto, de su desilusión y consecuente fatalismo.

Yasí es como vamos descendiendo

en la niebla hueca de la vida humana.

Hay una direccionalidad de descenso y caída. 


\section{Quizá porque}

Desde la infancia hasta un lugar perdido, desde una plenitud hacia una caducidad; desde el vientre materno a la fosa sepulcral.

Somos ángeles expulsados y expatriados del reino. Hemos perdido la verdadera casa, el divino útero materno, la morada imperecedera.

Somos desterrados del paraíso de la inocencia y la divinidad:

¿Conocerán el tiempo otro? Tal vez una inocencia oscura accedería, como dolorosa llaga, en la raíz de lo vivido, el tiempo deviniendo bajo inmóvil materia.

Pero nuestra pureza ya la hemos perdido, o mora en un dominio de pavorosos gestos.

Todo ha devenido en muerte, en falso lenguaje y hasta en gestos impropios.

Hay un origen poderoso, sublime y pletórico, pero la línea que hemos seguido es nefasta. Dejando lo glorioso hemos sucumbido y caducado.

La suya es poesía de la desilusión y la desesperanza por la esterilidad del mundo.

Quizá porque se ha amado tanto... debido a que se ha esperado mucho...

Porque cuando se tiene una idea tan alta y es tan elevado el propósito también deviene profundo el desencanto.

\section{Nada alumbra}

Pero tú yaces oculto o simulas alejarte
de lo que, en verdad, es tu único misterio:
en la innoble morada de la realidad
nutres un sentido más hondo,
del que ya ha cesado todo vestigio humano.

Arte de navegar es, paradójicamente, la elegía de un naufragio, la rapsodia de una catástrofe.

Una desgracia en vez de un arte, donde todo es fatal y se avizoran solamente despojos.

Permanecen las ruinas de lo que ha sido casa, palacio, pueblo y ciudad. La mirada conturbada desciende a las regiones del espanto, de los restos putrefactos, del abandono de Dios. 


\section{Los desgarrados, esos que recogen, sin saberlo, la pavorosa carencia del mundo y, transfigurados, soportan el misterio y habitan una soledad deforme.}

Alguien se burla de nosotros. Hemos sido engañados. Dios juega con el Hombre. Hay un fraude que no concluye y ni siquiera es fraude pleno sino esbozo fraudulento, y todo es mueca y farsa.

Y hay quienes no se desilusionan de nada, porque nada avizoran, nada alumbra sus espíritus, a nada aspiran.

\section{El dios ausente}

La poesía de Juan Ojeda es la construcción de una estructura ausente. Es el vacío de Dios. Y la enajenación no es porque éste sea distante e inasequible sino porque no es habido; porque al regreso de la anhelante búsqueda la respuesta es que el lugar que ocupaba está vacío, es hueco y yace abandonado. Dios ha huido dejando su creación desamparada:

Sobre la tierra una ausencia de dioses.

Ha explorado todo, ha sometido todo a un arduo proceso de verificación. Ha destejido y vuelto a tejer verdades antiquísimas y nuevas. Es buscador infatigable de bases y principios. Pero el resultado es que no hay nada. Todo es pavor, horror y miseria.

\section{Habitamos el cadáver de un Dios.}

El mundo ha devenido así en un páramo, en un espacio inerte y sin sentido. No hay nada que produzca felicidad ni alegría. No hay ninguna razón valedera, porque nada se mantiene en pie: todas las efigies y las estatuas han caído corroídas.

Ahora bien, Juan buscó a Dios en la realidad y entre las cosas. Con unos instrumentos como la racionalidad enloquecida, la lógica implacable, la ciencia y hasta la impotente erudición.

\section{El privilegio de la duda}

No lo buscó con candor e ingenuidad, como haría un hombre de fe, atributos estos que estaban lejos de ser comprendidos y adoptados por Ojeda.

Mucho menos lo hace con el temblor del amor fervoroso. Es que quiso hacerlo con libertad plena, con lo que consideraba infalible y apostando a que el veredicto constituyera un riesgo total. 
Siempre habla en Arte de navegar de haber encontrado una verdad secreta y temible. De haber desentrañado un signo letal en nuestras vidas, de tener una clave que lo hace un desesperado y hasta un destructivo. Él ha ingresado a un arcano, a un significado pavoroso:

$$
\begin{aligned}
& \text { Oh, ya hemos conocido } \\
& \text { el tiempo, ya hemos ordenado el pasado y el futuro } \\
& \text { en el hórrido escombro de un presente irredimible, } \\
& \text { y todo es como nacer desde la tierra muerta, } \\
& \text { tiempo muerto entre muertas raíces. } \\
& \text { ¿Es esta la región verdadera, o te has confundido? } \\
& \text { ¿Qué ruidos son esos? ¿Quién grita? }
\end{aligned}
$$

Respecto a Dios él no tuvo ya dudas, no golpeaba aún con afán una puerta para que la abrieran, guardando la ilusión de que adentro haya alguien y la verdad que buscaba afanosamente.

¡Éste ya no es su caso! A él no le queda el privilegio de la duda, de la esperanza por develar.

\section{Misterio y herejía sagrada}

Entró y salió del arcano. Y su testimonio y verdad terrible es que allí dentro no hay nadie.

La poesía de Juan, pese a que en la superficie es tersa, en sus significados es simbólica y trabada: no hace concesiones allanándose al lector. No se inmuta por ser clara u opaca.

Se sabe situada más allá de todo bien y de todo mal, inalcanzable a cualquier juicio, despercudida de todo canon, de toda referencia con este mundo. Es una poesía oscura, intrincada y barroca.

Y en su vida Juan era así: condescendiente y amable para responder cualquier saludo, pero sabiéndose de una esfera que no tenía nada que ver con esto que tocamos; batido y librando una guerra a muerte en otro plano; con códigos secretos y lenguajes cifrados, de regreso ya de todo lo previsible.

Poesía, la suya, opaca pero de inefable grandeza, en los momentos más solemnes de la cual aparece un ave, o la presencia de un animal libre y salvaje, o de un instrumento musical intacto.

Todo lo que aparece en ella es como si se tratase de una aparición mística, sea un ciervo, una corza, un gamo, un estornino, un sistro. 
Se escucha repentino el canto de un tordo o el vuelo asustadizo e íntimo de un gorrión.

\section{A veces inhallable}

Habrá lectores que se afanen por explicarla o comprenderla con el sentido de la racionalidad. En tal intento sin duda habrá mucho que quedará oculto; pero no hay que desesperar.

La poesía es precisamente tal por ser incógnita y misterio, presencia de lo divino y secreto aunque, de alguna manera, desbordante y promisorio.

Éste es el caso del libro Arte de navegar que sostenemos ungidos, que arrasa y castiga pero también inviste y ennoblece, si no por su fondo torturado, sí por la autenticidad y devoción con que está pergeñado.

Y porque es el testimonio por el cual se consagró y ofrendó una vida.

Poesía que sintetiza pensamientos, ciencias, artes, saberes y filosofías. Poesía ética y conceptual, herética y a la vez sagrada, con un repertorio muy grande de imágenes, alucinante en sus lamentaciones.

Nada de mundana, callejera o desvergonzada; que desaparece de la superficie de los días para sumergirse en un espacio y tiempo suprarreales.

Que nos hunde en su espíritu, en sus fantasmas y obsesiones; a veces inhallable, donde no hay estridencia, banalidad, ni lugar para lo veleidoso y lamentablemente tampoco para la piedad. 